\title{
Molecular Evolution of Viruses - Past and Present
}

\section{Evolution of Viruses by Acquisition of Cellular RNA and DNA}

\author{
edited by
}

\author{
Yechiel Becker \\ Department of Molecular Virology \\ The Hebrew University of Jerusalem \\ Jerusalem, Israel
}

and

Gholamreza Darai

Institute of Medical Virology

Ruprecht-Karls University

Heidelberg, Germany

Reprinted from VIRUS GENES

Volume 21, Nos. 1/2 (2000) 


\section{Library of Congress Cataloging-in-Publication Data}

Molecular evolution of viruses-past and present: evolution of viruses by acquisition of cellular RNA and DNA / edited by Yechiel Becker and Gholamreza Darai.

p. ; cm. - (Virus Genes; v. 21, no. 1/2)

Includes bibliographical references and index.

ISBN 978-1-4613-5688-2 ISBN 978-1-4615-1707-8 (eBook)

DOI 10.1007/978-1-4615-1707-8

1. Viral genetics. 2. Viruses-Evolution. I. Becker, Yechiel. II. Darai, Gholamreza.

III. Series

[DNLM: 1. DNA, Viral-genetics. 2. Genes, Viral-genetics. 3. Immune

System-physiology. 4. RNA, Viral—genetics. QW 165 M718 2000]

QR456.M65 2000

$579.2^{\prime} 138-\mathrm{dc} 21$

$00-042432$

Copyright $(02000$ Springer Science+Business Media New York

Originally published by Kluwer Academic Publishers in 2000

Softcover reprint of the hardcover 1 st edition 2000

All rights reserved. No part of this publication may be reproduced, stored in a retrieval system or transmitted in any form or by any means, mechanical, photo-copying, recording, or otherwise, without the prior written permission of the publisher, Springer Science+ Business Media, LLC

Printed on acid-free paper. 


\section{Virus Genes}

Volume 21, Nos. 1/2, August 2000

\section{Part A: Virus Genes Acquired to Evade the Host Immune Responses}

Evolution of Viruses by Acquisition of Cellular RNA or DNA Nucleotide Sequences and Genes: An Introduction . . . . . . . . . . . . . . . . . . . Yechiel Becker

Immunomodulatory Functions Encoded by the E3 Transcription Unit of Adenoviruses . . . . . . . .

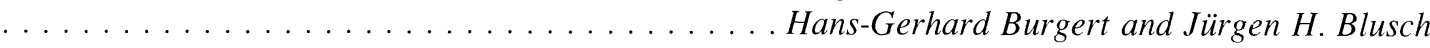

Immune Escape by Hepatitis B Viruses. . . . . . . . . . . . U. Protzer and H. Schaller

MHC Class I-Subversive Gene Functions of Cytomegalovirus and their Regulation by Interferons-an Intricate Balance. . . . . . . . . . . . . . . . . Christine Benz and Hartmut Hengel

Part B: Acquisition of Cellular and Viral Genes by Herpes and Iridoviruses

Marek's Disease Herpesvirus Transforming Protein MEQ: a c-Jun Analogue with an Alternative Life Style. . . . . . . . . . . . . . . . . . . . Juinn-Lin Liu and Hsing-Jien Kung

Herpesvirus Homologues of Cellular Genes . . . Martin Raftery, Anke Müller and Günther Schönrich

Iridovirus Homologues of Cellular Genes-Implications for the Molecular Evolution of Large DNA

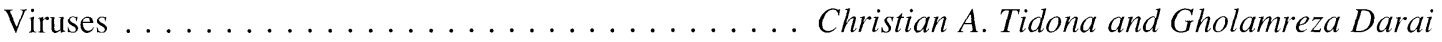

Part C: Poxvirus Gene Homologues of Cellular Genes

Sequence and Functional Analysis of a Homolog of Interleukin-10 Encoded by the Parapoxvirus Orf Virus . . . . . . . . . . . . . . . Stephen B. Fleming, David M. Haig, Peter Nettleton, . . . . . . . . . . . Hugh W. Reid, Catherine A. McCaughan, Lyn M. Wise and Andrew A. Mercer

Myxoma Virus Expresses a TNF Receptor Homolog with two Distinct Functions.

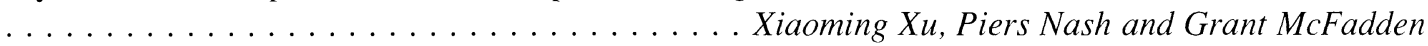

Poxvirus Homologues of Cellular Genes ............... Joachim J. Bugert and G. Darai 